\title{
Close linkage of three neuronal genes on distal mouse Chromosome 15
}

\author{
J.M. Jones, ${ }^{1}$ B. Ranscht, ${ }^{2}$ E.O. Berglund, ${ }^{2}$ S. Gruenheid, ${ }^{3}$ P. Gros, ${ }^{3}$ M.H. Meisler ${ }^{1}$ \\ ${ }^{1}$ Department of Human Genetics, 4708 Medical Sciences II, University of Michigan, Ann Arbor, Michigan 48108-0618, USA \\ ${ }^{2}$ La Jolla Cancer Research Foundation, 10901 North Torry Pines Road, La Jolla, California 92037, USA \\ ${ }^{3}$ Department of Biochemistry, McGill University, 3655 Drummond, Montreal, Quebec, Canada H3G 1Y6
}

Received: 25 March 1996 / Accepted: 7 May 1996

The mouse neurological mutant motor endplate disease (med) is located on distal Chromosome (Chr) 15. We recently identified mutations in the voltage gated sodium channel, Scn8a, that is encoded by the med locus (Burgess et al. 1995; Kohrman et al. 1996a,b). In the course of evaluating candidate genes for med, we refined the map positions of four genes that were previously assigned to this region either by in situ hybridization or by lowresolution genetic mapping: contactin (Cntn1; Gennarini et al. 1989), peripherin (Prph; Pendleton et al. 1991; Moncla et al. 1992), the calcium channel beta subunit 3 (Cchb3; Chin et al. 1995), and natural resistance-associated macrophage protein 2 (Nramp2; Gruenheid et al. 1995).

The genetic polymorphisms used in this study are described in Table 1. One hundred and eighty progeny from the intersubspecific backcross [(C57BL/6J-med $\left.\left.{ }^{\text {tg }} \times \mathrm{CAST} / \mathrm{Ei}\right) \mathrm{F}_{1} \times \mathrm{C} 57 \mathrm{BL} / 6 \mathrm{~J}\right](\mathrm{Kohr}-$ man et al. 1995) were analyzed (Fig. 1). The observed gene order and distances are: D15Mit34-2.2 $\pm 1.1 \mathrm{cM}-$ Cntn $1-5.0 \pm 1.6 \mathrm{cM}-$ D15Mit44, Nramp2, Prph, Cchb3-0.6 \pm 0.6-med ${ }^{\text {tg }}$ (Scn8a)-1.7 \pm $1.0 \mathrm{cM}-D 15$ Mit16-1.1 $\pm 0.8 \mathrm{cM}-$ D15Mit35.

To position these genes with respect to the rest of the chro-

Correspondence to: M. Meisler mosome, we typed Scn8a on The Jackson Laboratory BSS interspecific backcross (Rowe et al. 1994). Scn8a mapped to a position approximately $40 \mathrm{cM}$ distal to the centromere, between $\mathrm{D} 15 \mathrm{Bir} 17$ and D15Mit16 (Hoxc). Complete haplotype data for this cross are available electronically at http://www.jax.org/resources/ documents/cmdata.

Our results demonstrate that the brain sodium channel gene. Scn8a, the neuronal calcium channel beta subunit, and the neurofilament protein peripherin map within a 1-cM interval. The close linkage of these neuron-specific genes suggests that they might be regulated by shared cis-acting elements. These three genes, along with Nramp 2, Cntn1, and the Hoxc cluster, have been mapped to a conserved linkage group of human Chr 12q11-12q13 (Burgess et al. 1995; Collin et al. 1994; Moncla et al. 1992; Vidal et al. 1995; Berglund and Ranscht 1994). We have determined the gene order for six mouse loci in this linkage group, but the arrangement of the human genes has not been determined. The recently described YAC contig spanning human Chr 12 (Krauter et al. 1995) will facilitate comparative mapping of the human loci and identification of potential neuronal regulatory regions.
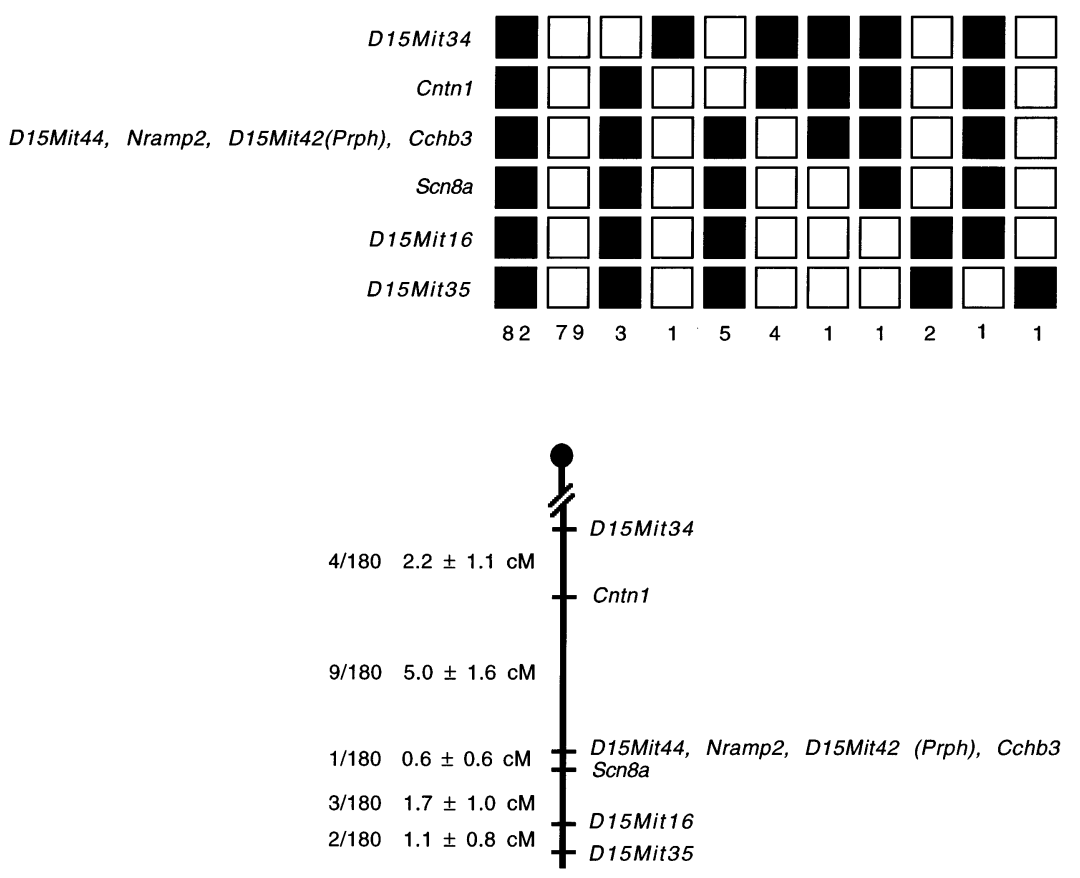

Fig. 1. Genetic map of distal mouse Chr 15. Genomic DNA from 180 backcross animals was typed for the indicated gene loci as described in the text. Each column represents one haplotype derived from the heterozygous backcross parent. The number of mice with each haplotype is indicated at the bottom of the column. Solid symbols, C57BL/6J alleles; open symbols, $\mathrm{CAST} / \mathrm{Ei}$ alleles. The derived genetic map is shown with distances in $\mathrm{cM}$. 
Table 1. Polymorphic loci on mouse Chromosome 15. Alleles for three strains are listed. nd, not done.

\begin{tabular}{|c|c|c|c|c|c|c|}
\hline Locus & Probe/Primers & Enzyme & C57BL/6J & $\mathrm{CAST} / \mathrm{Ei}$ & SPRET & Reference \\
\hline Cchb3 & rat cDNA mB1.7 & TaqI & 6.0 & $6.0,4.8$ & nd & M. Uhler \\
\hline Cntnl & mouse cDNA & TaqI & $\begin{array}{l}8.7,3.8 \\
3.5,2.1\end{array}$ & $\begin{array}{l}19.0,5.0, \\
1.7\end{array}$ & $\begin{array}{l}\text { nd } \\
\text { nd }\end{array}$ & $\begin{array}{l}\text { B. Ranscht and } \\
\text { E. O. Berglund }\end{array}$ \\
\hline Nramp2 & SCA3/SCA5 & PCR & 0.35 & 0.22 & nd & Gruenheid, 1995 \\
\hline Prph & mouse cDNA $5 \mathrm{~g}$ & TaqI & 8.8 & 1.8 & nd & Landon et al., 1989 \\
\hline Prph & D15Mit42 & PCR & 0.188 & 0.170 & nd & Dietrich, 1994 \\
\hline Scn8a & $6-7$ & TaqI & 1.7 & nd & 2.3 & Kohrman et al., 1995 \\
\hline Scn8a & med $^{t g}$ & PCR & neg & neg & neg & Kohrman et al., 1995 \\
\hline
\end{tabular}

\section{References}

Berglund, E.O., Ranscht, B. (1994). Molecular cloning and in situ localization of the human contactin gene (CNTN1) on Chromosome 12q11q12. Genomics 21, 571-582.

Burgess, D.L., Kohrman, D.C., Galt, J., Plummer, N.W., Jones, J.M., Spear, B., Meisler, M.H. (1995). Mutation of a new sodium channel gene. Scn8a, in the mouse mutant 'motor endplate disease'. Nature Genet. 10, 461-465.

Chin, H., Kwon, O-J., Jung, H.H., Kim, D.S., Kozak, C.A. (1995) Genetic mapping of the mouse genes encoding the voltage-sensitive calcium channel subunits. Genomics 28, 592-595.

Collin, T., Lory, Pl, Taviaux, S., Courtieu, C., Guilbault, P., Berta, P., Nargeot, J. (1994). Cloning, chromosomal location and functional expression of the human voltage-dependent calcium channel beta-3 subunit. Eur. J. Biochem. 220, 257-262.

Dietrich, W. (1994) In Genetic Map of the Mouse, Database Release 9 (Cambridge, Mass: Whitehead Institute/MIT Center for Genome Research).

Gennarini, G., Cibelli, G., Rougon, G., Mattei, M.-G., Goridis, C. (1989). The mouse neuronal cell surface protein F3: a phosphatidylinositolanchored member of the immunoglobulin superfamily related to chicken contactin. J. Cell. Biol. 109, 775-788.

Gruenheid, S., Cellier, M., Vidal, S., Gros, P. (1995). Identification and characterization of a second mouse Nramp gene. Genomics, 25, 514525 .

Kohrman, D.C., Plummer, N.W., Schuster, T., Jones, J.M., Jang, W., Burgess, D.L., Galt, J., Spear, B.T., Meisler, M.H. (1995). Insertional mutation of the motor endplate disease (med) locus on mouse Chromosome 15. Genomics 26, 171-177.
Kohrman, D.C., Harris, J.B., Meisler, M.H. (1996a). Mutation detection in the med and med $^{\mathrm{J}}$ alleles of the sodium channel Scn8a: unusual patterns of exon skipping are influenced by a minor class AT-AC intron. J. Biol. Chem. (in press).

Kohrman, D.C., Smith M.R., Goldin, A.L., Harris, J.B., Meisler, M.H. (1996b). A missense mutation in the brain sodium channel gene Scn8a is responsible for cerebellar ataxia in the mouse mutant jolting. J. Neurosci (in press).

Krauter, K., Montgomery, K., Yoon, S.J., LeBlanc-Straceski, J., Renault, B., Marondel, I., Herdman, V., Cupelli, L., Banks, A., Lieman, J. (1995) A second-generation YAC contig map of human chromosome 12. Nature 377 Suppl, 321-333.

Landon, F., Lemonnier, M., Benarous, R., Huc, C., Fiszman, M., Gros, F., Portier, M.-M. (1989). Multiple mRNAs encode peripherin, a neuronal intermediate filament protein. EMBO J. 8, 1719-1726.

Moncla, A., Landon, F., Mattei, M.-G., Portier, M.-M. (1992). Chromosomal localisation of the mouse and human peripherin genes. Genet. Res. 59, 125-129.

Pendleton, J.W., Violette, S.M., Hunihan, L.W., Greene, L.A., Ruddle, F.H. (1991). The peripherin gene maps to mouse chromosome 15. Genomics 9, 369-372.

Rowe, L.B., Nadeau, J.H., Turner, R., Frankel, W.N., Letts, V.A., Eppig, J.T., Ko, M.S.H., Thurston, S.J., Birkenmeier, E.H. (1994). Maps from two interspecific backcross DNA panels available as a community resource. Mamm. Genome 5: 253-274.

Vidal, S., Belouchi, A.-M., Cellier, M., Beatty, B., Gros, P. (1995). Cloning and characterization of a second human NRAMP gene on chromosome 12q13. Mamm. Genome 6, 224-230. 